\title{
A Review on Mycoremediation-the fungal bioremediation
}

Duryal Barrech ${ }^{1 *}$, Imran Ali ${ }^{1}$ and Malik Tareen ${ }^{2}$

1. Institute of Biochemistry, University of Balochistan, Quetta-Pakistan

2. Department of Microbiology, University of Balochistan, Quetta-Pakistan

*Corresponding author's email: duryal_barrech@yahoo.com

Citation

Duryal Barrech, Imran Ali and Malik Tareen. A Review on Mycoremediation - the fungal bioremediation. Pure and Applied Biology. Vol. 7, Issue 1, pp343-348. http://dx.doi.org/10.19045/bspab.2018.70042

\begin{tabular}{llll}
\hline \hline Received: 04/01/2018 & Revised: 25/02/2018 & Accepted: 06/03/2018 & Online First: 07/03/2018 \\
\hline \hline
\end{tabular}

\section{Abstract}

The ecofriendly management for the disposal of waste sludge and waste water is basic problem of treatment plants. The attention of public towards environment is very essential element for the survival of both man and biotic organisms. There is no such methods which can sufficiently work to degrade the toxic material. The better way to maintain the beauty and healthy environment is to adopt a method in which all the macro components return back in a recycle manner thus the waste can be convert to valuable and will give benefits to biotic and a biotic ecosystem. This review talks on the biological techniques which has been used for the waste degradation process. Mycoremediation is an advance biotechnology which uses fungi for the cleaning and controlling of hazardous contamination. It is frugal method and the final product is nonhazardous.

Keywords: Bioremediation; Mushroom; Mycoremediation; White root fungi

\section{Introduction}

Biotechnology can be defined as a methodology which utilize the living organism to bring out new products and improve the quality and reduce the human suffering [1]. Biotechnology simply defined as technological use of biological structures, living creatures or their derivatives to create and transform processes for its better and specific use and the end products can use for particular usage [2]. Customarily for the fermentation of food and the production of beverages microorganism have been usually used. Natural biotechnology assumes a critical part in agroecology in the correct execution of zero waste administration in agribusiness and most fundamentally through the operation of more than 15 million biogas digesters around the world. Risky contaminants are harmful to man and different living organisms like farm animals, livestock and vegetation in widespread. Clearly occurred microorganism degrades contaminants through their metabolic processes and this property of microbes has been exploited in bioprocess generation. Micro-organism can also degrade risky natural waste such an polycyclic aromatic hydrocarbons (PAH) insecticides, polychlorinated biphenyls (PCBs) metals, nitrogen compounds, halogenated organic solvents and compounds, nonchlorinated insecticides and herbicides, and radio nuclides without difficulty.

Deeds of people constitute one of the essential approach of advent of heavy metals into the environment. One of the most important development demanding situations dealing with this era is how to reap a fee powerful and environmentally sound techniques to cope with the global waste disaster facing each 
advanced and developing countries. Waste contains heavy metals, toxic organic chemicals, salts, excessive pH [3]. The pollution of heavy metals in environment in a low quantity and their effects on health and their resistance is the major issue of new era, as instance the bioaccumulation of $\mathrm{Mg}$ and $\mathrm{Pb}$ can affect the function of mitochondria thus this all damage the respiration, swelling of brain, paralysis and finally death [4]. Current growth rate, industrial establishment and development has increased production of municipal industrial and domestic wastes. These all wastes are discarded in landfill and sea without any initial treatment [5]. Explained that the utilization of agriculture area for the disposal of waste is usually performing in cities and in villages. These wastes mostly have heavy metals in different arrangement and their contamination is also has different levels of bioaccumulation. Heavy mwtals such as $\mathrm{As}, \mathrm{Cd}, \mathrm{Pb} \& \mathrm{Hg}$ these are mainly toxic to all plants, wild life $\&$ human beings [6].

By utilizing enzymes microorganisms are stretching their living area these enzymes use for the metabolism of various xenobiotics and other man-made chemicals. The process which detoxify and degrade the environmental contamination by the use of microorganism and their processes is known as bioremediation. From several years the microorganism have been used for the treatment and alteration of waste effluents [7]. The removal of heavy metals from environment via the use of microorganism is carried by several mechanism for example adsorption to cell surfaces, mix of exopolysaccharides, inside the cell accumulation, synthesis in metallothionine and several different protein that can set up metals in them and convert it in unstable compounds [8]. As we know that the use of microorganism and plants for the disposal of contamination as in the form of sewage, domestic waste, farms, agro land an industrial waste to make it reduce and detoxify it by usual processes.

\section{Methods of bioremediation}

Bioremediation can be followed by these three methods.

phytoremediation and bacterial bioremediation.

a) Mycoremediation the use of fungi for the removal of organic contaminants from the land and water. To make the contaminants less toxic and non-hazardous, the fungus exploit the certain enzymes and acids in this method as this is one of the current method for the removal and decomposition of contaminants. [9].

b) Phytoremediation the removal of pollution from soil, water and air the plants has been used for this process. The contaminants such as complex organic and inorganic compounds such as metals, sewage, leachates, sludge, salts and xenobiotic has been removed through this process.

c) Bacterial Bioremediation Environment contamination such as oil spills, mine waste and human waste can be clean up by natural metabolic processes of bacterial activity and bacteria is make in use for this particular method.

The sludge of sewage is top graded contamination [10]. The remedies are less but the problem generating ratio is high. The management need high investment and technological trials [11]. As per evaluating the problems the management of wastewater in treatment plants need extra efforts as the sludge contain more than $90 \%$ of water which cause issue in removal and discard [12]. As the solid sludge be able to easily treated and can be again use for the bio-solids [13] in every waste water treatment plant the discard of waste water sludge is a demanding issue. Many regular treatments are followed for the disposal of waste water sludge such as land filling, incineration, duping in sea and free lands, sun drying and use in crop field. Not a single treatment has resolve the issue 
completely as by use of these all treatments some quantity of contamination is dispersing in the surrounding and leachate can reach to the groundwater as well $[14,15]$. Some recent treatment techniques such as polymers advance chemical usage filtration and flocculation has been experienced but these all are costly as well as erudite and some of these are not suitable in elimination of soluble toxic substances [15]. Researchers and different environmental agencies are engrossed to focus on biological treatment which are more ecofriendly and are cost-effective as well [16, 17]. Biotransformation, bioaccumulation, biosorption, bioseparation, biodegradation, biobleaching, biodetoxification, these all are known as methods which are useful to eliminate the contaminants present in air, soils and water by the use of microorganisms. These all usually chosen as "bioremediation." This is capable of degradation process which is ecofriendly [18], the technique which uses microbes can destroy/remove the pollution present in environment [19]. Compare with physical and chemical systems this is higher [20]. Microbes are perform important role as changing the solid wastewater substances and fabric wastewater in biological systems [21] and it will also improves bio sorption of SS (suspended solids) captured in filamentous structure especially fungi which can increase the filterability and dewater ability and can pre clean the residential wastewater sludge treatment of wastewater sludge is effective way although it can create some downsides and make heavy numbers of large sludge. But the new research on filamentous fungi and their use in domestic wastewater pre cleaning test which improve the dewatering and filterability problems are remarkable. The outcome of liquid state bioconversion (LSB) is undeniably good it is not practicable in commercial action plants as this all process carry in pre-cleaned home waste water sludge. Hence system is require that can carry and apply on common or raw wastewater sludge situation too. The recent studies are going on to estimate the filamentous fungi for mycoremediation process that can be bio separation of SS (suspended solids) and safe management for the dewatering of raw home wastewater sludge.

Some extremophiles organisms shown good results in biotechnological uses and as we know that these organisms can live under extreme physical condition so they can survive in harsh environment as well [22]. And can be used their biological fluid for breakdown of organic materials. That is the reason that we are studying it mostly.

The water with salinity or simply the sea water are the foundations which provide marvelous area to the microorganisms which can provide interested industrial enzymes beta carotene and ectoine are bioactive compounds made for theses industrial processes. Halophiles can be used in fermentation practices. The active enzymes has been utilize in biorhodopsin, biosurfactant which has increase the biodegradation and exopolysaccharide for oil rescue [23]. as the water which is hard in nature as saline water which is not good for drinking, so we can store the drinking water and by the use of alpha amylase we can clean our laundry and as well this alpha amylase may give good result in cleaning water purpose.

\section{Role of Mushroom in mycoremediation}

Fungi and mushroom has been used for the exclusion of waste from the environment. Mushrooms and other fungi release enzymes which decompose large quantity of waste [24, 25]. Mushrooms has fruiting body or mycelium as a way of protein. The productivity of mushroom is providing food protein by the way of biomass in the form of diverse wastes present to reduce waste and emission of different kind hydrolases and oxidoreductase. Though mushroom basidiomycetous fungus are emerging more famous in recent years for the remediation process as it is one of important 
bioremediation instrument [26]. The remediation process has fascinated the curtesy of many scholars and researchers and they are faming mushrooms, some are highlighted the mushroom role as biosorption and biodegradation [27]. The enzymes such as peroxidases, ligninase cellulases and oxidases can be produced extracellular by mushroom [28]. These enzymes are capable of oxidize the unmanageable waste in laboratory. The substances encouraged these enzymes classically. These enzymes has been remove the pollutants like nonpolymeric recalcitrant such as nitrotoluenes, PAHs [29] organic \& manmade colorants. In the control environmental condition. Currently it is informed as mushrooms are capable of decomposing polymers such as plastics [30]. The process of biodegradation is much complicated. On the other hand the farming of mushrooms will lessen two major issue of world that is waste accumulation and providing food with proteins at the same time. White root fungi role in mycoremediation In the fungi species the white root fungi WRF are showing positive result in mycoremediation process as it can effectively mineralize lignin [31]. The extra cellular enzymes are released such as lignin peroxidase (Lip). Manganese peroxidase $(\mathrm{MnP}) \&$ laccase [32]. These enzymes are able to lower organic waste product those who have same molecular arrangement [33]. As humics substances (HS) effect of animal and plants decomposing tissues [34]. White root fungi is basically used to eliminate the contamination from water and to provide awareness about enzyme linked mechanism. Researchers study has been done under germ-free surroundings for fungal growth and further activity like enzyme production by usage of better distinct media. The main purpose of their studies were to find out the process of powerless WRF on grain sorghum to eliminate the HA from contaminated useless water which is not properly sterilized. Different biological materials like starch, proteins lipids, fiber ash along with vitamins were found in this process. In this process they use sorghum expecting that in access to nutrients sorghum will provide benefits to fungi over bacteria that's why they use sorghum as exporter material (to control fungi) rather than defined media. To approve the capability of Sorghum for fungal growth and enzyme activity while removing the HA from imitation contaminated water Mycoremediation trials were early achieved under disinfected circumstances. To appraise the capability of powerless white root fungi and to eliminate the HA from contaminated water the different experiments were performed in tainted conditions. Experiment was conducted in the last to testify different waste water with the similar fungal biomass to note down strength of fungal immobilized on sorghum and to assess the use for future studies.

\section{Conclusion}

The management of waste through fungi is regard as mycoremediation which declare the positive result on bio separation and bio filtration of raw home waste water sludge. The fungal mycelia has filamentous structure which increase the bioremediation of sludge. Hazardous contamination are harmful for man, other livestock and plants. Microorganisms can degrade PAH, PCB, insecticides, hydrocarbons, organic complex compounds and radio nucleoid without difficulty. By utilizing enzymes microorganisms are degrading the toxic material. Mushrooms and other fungi release enzymes which decompose large quantity of waste. Mushrooms has fruiting body or mycelium as a source of protein. The enzymes such as peroxidases, ligninase, cellulases and oxidases can be produced extracellularly by mushroom. These enzymes are capable of oxidize the unmanageable waste in laboratory. In the fungi species the white root fungi WRF are showing positive result in mycoremediation process as it can effectively 
mineralize lignin. The extra cellular enzymes are released such as lignin peroxidase (Lip), manganese peroxidase $(\mathrm{MnP}) \&$ laccase. These enzymes are able to lessen organic wastes and other plants decaying wastes. The mycoremediation is cost-effective and nontoxic treatment methods for the waste management. And it is ecofriendly as the byproduct convert into simple compounds and it is utilized in the environment.

\section{Authors' contributions}

Data collected by: D Barrech, I Ali \& M Tareen, Wrote Paper: D Barrech \& I Ali.

\section{References}

1. Olatunji O (2007). Biotechnology and Industries in Nigeria annual Conf. Biotech Soc of Nig J (BSNJ) 4: 36-38.

2. UNCBD (1992). United Nations Conference on Biological Diversity (Earth Summit) held in Brazil. Rio De J Brazil.

3. Cameron KC, Digmi HJ \& McLaren RG (1997). Is soil an appropriate dumping ground for our wastes? Aust J Soil Res 35: 995-1035.

4. Chang LW (1992). The Concept of Toxic Metal/Essential Element interactions as a common biomechanism underlying metal toxicity. In Toxins in Food Plenum Press New York 8: 15-61.

5. Ogunyemi S, Awodoyin RO \& Opadeji T (2003). Urban agricultural production heavy metal contamination of Amaranthus cruenties L. grown on domestic refuse landfill soil in Ibadan, Nigeria. Emir J Agric Sci, 15: 87-94.

6. Alloway BJ \& Ayres DC (1997). Chemical Principles of Environmental pollution. Blackie Academic and Professional 353359.

7. Okpokwasili GC \& Odokuma LO (1996). Response of Nitrobacter specie to toxicity of drilling chemicals. J of Petrol Sci Eng, 18: 8187.

8. Bitton G \& Frechoffer V (1978). Influence of extracellular polysaccharides on the toxicity of copper and cadmium towards K. aerogenes. Microb Ecol 4: 119-125.

9. Barry DP \& Austa SD (1994). Pollutant degradation by white rot fungi. Review of Environmental Contamination and Toxicology 138: 49-72.

10. Cheremisinoff PN (1994). The Sludge management and disposal. Management review. Prentice-Hall Englewood Cliffs, 7: $1-4$.

11. Bastian R (1997). The biosolids (sludge) treatment, beneficial use and disposal situation in the USA. Eur Water Pollute Cont J 2: 62-79.

12. More TT, Yan S, Tyagi RD \& Surampalli RY (2010). Review-potential use of filamentous fungi for wastewater sludge treatment. Bioresour Technol 110: 76917700.

13. Yan S, Mohammedi S, Tyagi RD, Surampalli RY \& Valéro JR (2007). Growth of four serovar of Bacillus thuringiensis (Var. Kurstaki, Israelensis, Tenebrionis, and Aizawai) in wastewater sludge. Pract Period Hazard Toxic Radioact Waste Manage 11: 123-129.

14. Eljarrat E, Caixach J \& Rivera J (2001). Evaluation of dioxin contamination in sewage sludge discharges on coastal sediments from Catalonia, Spain. Water Res 11: 2799-2803.

15. Lorain O, Thiebaud P, Badorc E \& Aurelli $Y$ (2001). Potential of freezing in wastewater treatment soluble pollutant applications. Water Res 35: 541-547.

16. Cameron MD, Timofeevski S \& Aust SD (2000). Enzymology of Phanerochaete chrysosporium with respect to the degradation of recalcitrant compounds and xenobiotics. Appl Microbiol Biotechnol, 54: 751-758.

17. Alam MZ, Fakhru'l-Razi A, Abd-Aziz S $\&$ Iris A (2001). Bioconversion of wastewater sludge by immobilized microbial treatment. International Water Association IWA Conference on Water 
and Wastewater Management for Developing Countries Kuala Lumpur 344-353.

18. Desai JD \& Banat IM (1997). Microbial production of surfactants and their commercial potential. Microbiol Mol Biol Rev 61: 47-64.

19. Colwell RR (2009). Scientific foundation of bioremediation and gaps remaining to be filled. Res Microbiol 145: 40-41.

20. Lee LB \& Mat HB (2011). Biodegradation of lubricating oil by locally isolated bacterial species-microbial identification and degradation potential study. In: Proc. 10th National Biotechnology Seminar, 27: 80-85.

21. Palma C, Moreira MT, Mielgo I, Feijoo G \& Lema GM (1999). Use of a fungal bioreactor as a post treatment step for continuous decolorisation of dyes. Water Sci Technol 40: 131-13.

22. Ali IL, Kanhayuwa S, Rachdawong SK \& Rakshit (2013). Identification, phylogenetic analysis and characterization of obligate halophilic fungi isolated from a man-made solar saltern in Phetchaburi province, Thailand. Ann Microbiol 63: 887- 895.

23. Ali I N, Siwarungson H \& Punnapayak (2014). Screening of potential biotechnological applications from obligate halophilic fungi, isolated from a man-made solar saltern located in Phetchaburi province, Thailand. Pak $J$ of Bot. 46: 983-988.

24. Purnomo AS, Mori T, Putra SR \& Kondo $R$ (2013). Biotransformation of heptachlor and heptachlor epoxide by white-rot fungus Pleurotus ostreatus. Inter Biodeterior Biodegrad 82: 40-44.

25. Kulshreshtha S, Mathur N \& Bhatnagar P (2013). In: Fungi as Bioremediators: Soil Biology. Goltapeh EM, Danesh YR, Varma A, editor. Springer Berlin, Heidelberg. Mycoremediation of paper, pulp and cardboard industrial wastes and pollutants; pp. 77-116.

26. Kuforiji OO \& Fasidi IO (2008). Enzyme activities of Pleurotus tuber-regium

(Fries) Singer, cultivated on selected agricultural wastes. Bioresource Technol, 99: 4275-4278.

27. Akinyele JB, Fakoya S \& Adetuyi CF (2012). Anti-growth factors associated with Pleurotus ostreatus in a submerged liquid fermentation. Malaysian $J$ of Microbiology 8: 135-140.

28. Nyanhongo GS, Gübitz G, Sukyai P, Leitner C, Haltrich D \& Ludwig R (2007). Oxidoreductases from Trametes A wealth of catalytic activity. Food Technol Biotechnol 45: 250-268.

29. Hammel KE, Green B \& Gai WZ (1991). Ring fission of anthracene by a eukaryote. Proc Natl Acad Sci USA 88:1060510608.

30. Da Luz JMR, Paes SA, Nunes MD, Da Silva MCS \& Kasuya MCM (2013). Degradation of Oxo-Biodegradable Plastic by Pleurotus ostreatus. PLOS ONE 8: 69-86.

31. Kües U (2015). Fungal enzymes for environmental management. Curr Opin Biotechnol 33:268-278.

32. Hataka A, Steinbüchel A \& Hofrichter M (2001). Biopolymers lignin humic substances and Coal. Weinheim, Germany Wiley. Verlag GmbH \& Co. KGaA 1: 129-179.

33. Novotný C, Svobodová K \& Erbanová $\mathrm{P}$ (2004). Ligninolytic fungi in bioremediation extracellular enzyme production and degradation rate. Soil Biol Biochem. 36:1545- 1551 .

34. Zahmatkesh M, Spanjers H \& Vanlier JB (2017). Fungal treatment of humic-rich industrial wastewater application of white rot fungi in remediation of foodprocessing wastewater. Environ Technol 74: $1-11$. 